\title{
EFFICIENCY EVALUATION IN PUBLIC ROAD TRANSPORT: A STOCHASTIC FRONTIER ANALYSIS
}

\author{
Sami Jarboui ${ }^{1}$, Pascal Forget ${ }^{2}$, Younes Boujelben ${ }^{3}$ \\ ${ }^{1,3}$ Faculty of Economics and Management, University of Sfax, Tunisia \\ ${ }^{2}$ School of Engineering, University of Quebec at Trois-Rivieres, Canada \\ Submitted 1 October 2012; accepted 10 December 2012; \\ first published online 23 May 2013
}

\begin{abstract}
This paper measures the technical efficiency of 54 public road transport operators and investigates the degree to which various factors influence efficiency levels in these firms. The study makes an attempt to provide an overview of the general status of different operators in 18 countries. Stochastic Frontier Analysis (SFA) methods are applied to our sample over a twelve year period from 2000 to 2011. To our knowledge, this is the first comprehensive analysis of technical efficiency of public road transport operators in 18 countries using parametric method. Our empirical results indicate that investment, operating profit and firm size have a significant influence on technical efficiency levels. We find that technical efficiency level of public road transport operators varies between 0.458 and 0.95 . We also observe that large-size operators with more investment capacity tend to be more technically efficient than small-size operators. Finally, we find that operators from developed countries are technically more efficient than those of developing countries.
\end{abstract}

Keywords: public road transport; efficiency; stochastic frontier analysis; translog production function; stochastic model.

\section{Introduction}

In recent years, the economic growth of developing countries has led to an expansion of urban cities (Saxena, P., Saxena, R. R. 2010). Public road transport is effectively an important participant in citizens' mobility and is a fundamental component in the quality of life available to citizens (García Sánchez 2009). The transport sector plays a significant role in the overall development of a nation's economy. Road transport is the primary mode of transport, linking remote areas with the rest of the country (Agarwal et al. 2010). In the absence of a transport system, dependency on personalised modes of transport increases leading to waste of energy (Saxena, P., Saxena, R. R. 2010). Generally, public road transport operators of passenger vehicles offer a public service with a social aim. In most cases, they are controlled by the government. Efficiency evaluation in public transportation is therefore an issue of foremost importance.

Efficiency has long been a critical consideration in both policy and operational decisions of public transport operators, and public transport efficiency has recently become even more vital (Barnum et al. 2011). Passenger road transportation is a 'service business' and evaluating the efficiency of a service business is a complex matter. Transport efficiency is often more difficult to evaluate than manufacturing business efficiency, because it is difficult to determine the correct amount of resources required to produce various service outputs. The manufacturing standard can be used to identify operating inefficiencies through classical cost accounting variance analyses. However, in service organisations like the road passenger transportation system, it is difficult to identify the specific resources required to provide a specific service output (Agarwal et al. 2010).

Several approaches have been adapted to measure transport operators' efficiency. Parametric and nonparametric frontiers are the two main approaches used to measure technical efficiency (Jarboui et al. 2012). The parametric frontier approach (Aigner, Chu 1968; Aigner et al. 1977; Meeusen, Van den Broeck 1977) establishes a functional form for the cost, profit, or production relationship among inputs, outputs, and environmental factors, and allows for random error. Both inefficiencies and random errors are assumed to be orthogonal to the input, output, or environmental variables determined in the estimating equation (Boame 2004). The non-para- 
metric approach, the Data Envelopment Analysis (DEA) method, was developed by Farrell (1957), Charnes et al. (1978) and Färe et al. (1985). The DEA frontier is formed as the piecewise linear combinations that connect the set of best practice observations, yielding a convex production possibilities set. DEA does not require explicit specification of the form of the underlying production relationship. The non-parametric approaches, however, do not allow for random error. If random error exists, measured efficiency may be confounded with these random deviations from the true efficiency frontier. As well, statistical inference and hypothesis tests cannot be conducted for the estimated efficiency scores (Boame 2004).

In empirical analysis of efficiency, debate still exists between the use of the parametric and nonparametric approach. There is a wide range of literature comparing the two approaches. Thus, Lovell (1993) offers a detailed presentation. Ferrier and Lovell (1990), for example, assessed the strengths and weaknesses of both approaches through an empirical analysis of cost efficiency in banking. Bjurek et al. (1990) have compared the two approaches as part of service production. Cullinane et al. (2006) have provided a technical efficiency analysis of container ports by comparing the parametric Stochastic Frontier Analysis (SFA) and DEA as a non-parametric approach, and highlighting the strengths and weaknesses of each approach.

According to the literature, the public transport efficiency works are always related to a specific study context, for example, Agarwal et al. (2010) and Kumar (2011) propose an Indian application, Yu and Fan (2009) use Taiwan data, and Von Hirschhausen and Cullmann (2010) study German data. Moreover, the efficiency operators' evaluations in different countries are difficult to follow. There is missing data of indicators and variables to measure different countries efficiency. So, the lack of comparative work of operators' efficiency in different countries has become an initiative for this research, but for this study, we select financial variables relating to operating activities operators'.

The aim of this paper is to assess the efficiency of 54 public transport operators in different countries between 2000 and 2011, using the SFA of the production function model specified by Battese and Coelli (1995) for panel data. Again, this study will identify the determinants of inefficiency in public transport operators of passenger services. In the literature, most research has shown that the market organisation, contract conception, regulatory system degree and nature, and network characteristics are the inefficiency determinants (De Borger et al. 2002). In this study, in addition to these determinants, we also consider investment, operating profit and firm size as explanatory variables of public transport inefficiency.

This paper is organised as follows. The next section presents public transport operators efficiency with some relevant literature on the public transport efficiency evaluation. Section 2 presents the stochastic frontier analysis models and the functional form used for measuring efficiency. Technical inefficiency modelling is dis- cussed in Section 3. Inputs and outputs used are defined in Section 4. Data used in this study are discussed in Section 5. Empirical results are presented in Section 6, and conclusions are drawn in the final section.

\section{Public Transport Operators Efficiency}

In economics, the term efficiency refers to the comparison between the observed values of outputs and inputs with the optimal values of the outputs and inputs used in a production process (Karlaftis, Tsamboulas 2012). Economic efficiency requires that producers of a good or of a service make the best use of the resources available to them. To properly define the concept of economic efficiency, it is necessary to distinguish between technical efficiency and allocative efficiency. Technical efficiency reflects the extent to which transport operators achieve maximum output with provided inputs. Allocative efficiency reflects the minimum level of inputs used to produce a certain level of output.

The literature on assessing efficiency or, more generally, public transport efficiency is extensive. Analyses have focused both on developing methods for assessing public transport efficiency and on using efficiency findings to make different policy recommendations (Karlaftis, Tsamboulas 2012). Such efficiency assessment studies have been very popular in public transport literature in large part because of the interest in reforming public transport operations and assessing the effects of these changes on efficiency. On this subject, Jarboui et al. (2012) offer an interesting overview.

Agarwal et al. (2010) measure the technical efficiency of 35 Indian transport operators through the DEA method. They obtain an average efficiency score equal to $83.26 \%$ and it is interesting that these operators will reduce their used quantity of inputs.

Barnum et al. (2011) identify the individual technical efficiencies of each type of transit employed in an urban area. The objectives are to identify allocation and technical efficiency in the DEA aggregated score, to estimate the effect of changes in each type of transit' efficiency on overall public transportation efficiency and to offer a method for reallocating resources in order to improve efficiency.

Kumar (2011) assesses the technical efficiency, pure technical efficiency and scale efficiency of 31 Indian public transport operators between 2006 and 2007. The results suggest that, by adopting best practices, transport operators can reduce their inputs by less than $22.8 \%$. The observed operators studied lose about a quarter of their resources in production operations. Kumar (2011) affirms that managerial inefficiency is the dominant source of technical inefficiency.

In studying 23 public transport companies in Taiwan, Yu and Fan (2009) showed that a unified DEA framework is constructed for gauging Production Efficiency (PE), Service Effectiveness (SEV) and Operational Effectiveness (OEV) simultaneously and dependently. The proposed model also deals with the situation where shared inputs are needed to allocate the activities and/or processes in the operation of a transit firm. 
Despite significant research in transport operators' efficiency, evaluation of inefficiency determinants is generally ignored. The majority of studies focus on the choice of empirical evaluation method and on measuring the technical efficiency of transport operators. The results of these studies showed that technical inefficiency relates to exogenous factors, and market organisation, regulatory system degree and nature and network characteristics are important inefficiency determinants (De Borger et al. 2002).

Most research that has studied the determinants of inefficiency has shown that inefficiency is always associated to exogenous factors outside the firm's control. These results are more interesting for policy-makers than transport operators. The purpose of public transport efficiency studies is to provide an explanation and results to improve public transport operators' efficiency; therefore, it is interesting to find inefficiency determinants which are directly related to transport operators. In his framework, Cowie (2002) affirms that improving transport operators' efficiency may be based on a number of sources such as improving work practices, better operations management and increased investment. It is worthwhile searching the most robust empirical methods to measure efficiency levels, but it is more interesting to find the determinants and sources of inefficiency which help us enhance efficiency.

\section{Methodology}

We adopt a parametric approach using the SFA model of production function for the panel data developed by Battese and Coelli $(1993,1995)$. As an alternative approach to the DEA, the great advantage of SFA is that it can measure not only technical inefficiency, but also recognises the fact that random shocks, beyond the control of producers, can affect production. For this reason, the essential concept of SFA is that the error term is composed of two parts: one unilateral component that captures the effects of the relative inefficiency of the stochastic frontier, and a symmetric component that allows a random variation of the frontier between companies and includes the effects of measurement error, other statistical noise, and random error. Thus, the main attraction of the stochastic frontier approach, in contrast to deterministic approaches such as the DEA, is that it isolates the influence of factors to inefficient behaviour, thus correcting possible upward bias of the inefficiency of deterministic methods. In addition, it allows us to study the determinants of inefficiency.

\subsection{Stochastic Frontier Analysis (SFA)}

The first objective of this study is to provide measures of technical efficiency of transport operators. We use the parametric approach using the stochastic frontier production function for panel data proposed by Battese and Coelli $(1993,1995)$. The starting point of this parametric approach is to estimate a stochastic production frontier.
According to Battese and Coelli $(1993,1995)$, this frontier can be written as follows:

$$
Y_{i t}=\exp \left(x_{i t} \beta+V_{i t}-U_{i t}\right),
$$

where: $Y_{i t}$ is the output of the $i$-th transport operator $(i=1,2, \ldots, N)$ in the $t$-th period $(t=1,2, \ldots, T)$ - although it is assumed that there are $T$ time periods for which observations are available for at least one of the $N$ firms involved, it is not necessary that all the firms are observed for all $T$ periods in this model specification; $x_{i t}$ is a $\left(1^{\star} k\right)$ vector of input quantities of the $i$-th transport operator in $t$-th period; $\beta$ is a $\left(k^{\star} 1\right)$ vector of unknown parameters to be estimated; $V_{i t}$ is a random variable which is assumed to be independent and identically distributed (i.i.d.) $N\left(0, \sigma_{V}^{2}\right)$ and independent of $U_{i t} ;$ the $U_{i t}$ is non-negative random variable, associated with technical inefficiency of production, which is assumed to be independently distributed as truncations at zero of the $N\left(\mu, \sigma_{U}^{2}\right)$ distribution; where $\mu=z_{i t} \delta$ and variance $\sigma_{U}^{2}$; and $z_{i t}$ is a $\left(1^{*} p\right)$ vector of explanatory variables associated with technical inefficiency of public transport production industry over time; where $\delta$ is a $\left(p^{\star} 1\right)$ vector of unknown parameters.

Equation (1) specifies the stochastic frontier production function in terms of the original production values. However, the technical inefficiency effects, $U_{i t}$, is assumed to be a function of a set of explanatory variables, $z_{i t}$, and an unknown vector of coefficients, $\delta$.

According to Battese and Coelli $(1993,1995)$, the technical inefficiency effect, $U_{i t}$, in the stochastic frontier model (1) is specified by equation (2):

$$
U_{i t}=z_{i t} \delta+W_{i t},
$$

where: $\delta$ is a $\left(p^{*} 1\right)$ vector of unknown parameters to be estimated; the random variable $W_{i t}$ follows truncated normal distribution with mean zero and variance $\sigma^{2}$, such that the point of truncation is $-z_{i t} \delta$ that is, $W_{i t}>-z_{i t} \delta$. These assumptions are consistent with $U_{i t}$ being a non-negative truncation of the $N\left(z_{i t} \delta, \sigma_{U}^{2}\right)$ distribution (Battese, Coelli 1993, 1995). The mean $z_{i t} \delta$ of the normal distribution, which is truncated at zero to obtain the distribution of $U_{i t}$, is not required to be positive for each observation (Reifschneider, Stevenson 1991).

The likelihood function and its partial derivatives with respect to the parameters of the model are presented in Battese and Coelli (1993). The method of maximum likelihood is proposed for simultaneous estimation of the parameters of the stochastic frontier (1) and the model (2) for the technical inefficiency effects. The likelihood function is expressed in terms of the variance parameters, $\sigma^{2}=\sigma_{V}^{2}+\sigma_{U}^{2}$ and $\gamma=\sigma_{U}^{2} / \sigma_{V}^{2}$.

After obtaining the estimates of $U_{i t}$, the Technical Efficiency (TE) of the $i$-th transport operator at $t$-th observation, Referring to Battese and Coelli $(1993,1995)$, is defined by equation (3):

$$
T E_{i t}=\exp \left(-U_{i t}\right)=\exp \left(-z_{i t} \delta-W_{i t}\right) .
$$




\subsection{The Functional Form}

After presenting the stochastic efficiency frontier of public transport operators, to this point the discussion has concentrated on the error component part of the models. However, it is important to note that the functional form of the production function is another issue that has attracted considerable interest in the literature (Karlaftis, Tsamboulas 2012). The stochastic frontier estimation requires a specific functional form of the production function. Different functional forms of the production function frontier are available. Many authors have estimated the stochastic frontier production function using the form of Cobb-Douglas function (Cobb, Douglas 1928):

$$
\ln Y_{i t}=\alpha_{0}+\sum_{i=1}^{M} \alpha_{i t} \ln x_{i t}+V_{i t}+U_{i t} \text {. }
$$

Many studies in public transport have shown that the underlying technologies are flexible (not of a CobbDouglas form) and have proposed other more flexible functional forms, such as the widely-used translog formulation (Karlaftis, McCarthy 1999, 2002; Karlaftis 2010). Translog form is a relatively flexible functional form, because it does not require assumptions about production constant elasticities (this represents the output variation from the input variation level) or substitution elasticity between the inputs (this represents the degree to which an input is able to substitute another result of relative changes in inputs prices while maintaining the output constant; the values vary from 0 (which indicates that the inputs are used in fixed proportions and are not substitutable) to infinity (in this case, the inputs are perfect substitutes and their use is very sensitive to relative price variation)). Baten et al. (2009) have shown that the translog production function form is more preferable than the Cobb-Douglas form. The translog form allows the data to indicate the real curve of the function, rather than imposing a priori assumptions. According to Christensen et al. (1973), this can be expressed as equation (5):

$$
\ln Y_{i t}=\alpha_{0}+\sum_{i=1}^{k} \alpha_{i t} \ln x_{i t}+\sum_{i=1}^{k} \sum_{j=1}^{k} \alpha_{i j t} \ln x_{i t} \ln x_{j t}+V_{i t}-U_{i t} \text {, }
$$

where: $Y_{i t}$ is the output produced by the public transport operator $i(i=1,2, \ldots, N)$ in period $t(t=1,2, \ldots, T)$; $\alpha_{0}$ is a constant; $x_{i t}$ and $x_{j t}$ are the row inputs vector of operator $i$ during period $t ; V_{i t}$ is the random error term and $U_{i t}$ is the inefficiency of operator $i$ in period $t$.

We note that when $\alpha_{i j t}=0$, the translog function reduces to a Cobb-Douglas form.

\section{Inefficiency Modelling}

Improving performance and efficiency is one of the objectives of public transport operators. After technical efficiency measuring, it is necessary to determine inefficiency sources and determinants. The second objective of this study is to identify the explanatory variables of public transport operators' inefficiency. Several studies have examined the inefficiency determinants of public transport, but they tend to focus on the variables outside the firm's control. De Borger et al. (2002) have shown that market organisation, contract conception, regulatory system degree and nature, and network characteristics are the inefficiency determinants. In most cases, operators are unable to act on these determinants that are outside the control to improve their efficiency. In fact, there are other more robust determinants, such as investment, operating profit and firm size, that have a major effect on firm performance and they are usually ignored in empirical studies of public transport efficiency. In this study, we adopt variables under the firm's control to explain the transport operators' inefficiency.

Mohapatra and Dutta (1990) affirm that the investment decision is critical to public transport passengers' performance. In addition, Ahern and Anandarajah (2007) study the priority of investment in the transport sector. They show that investment is a necessity for improving quality, reliability and transportation system security, and to increase passenger demand for use of public transport services. Therefore, investment is an important determinant of public transport operators' efficiency.

The investment decision depends on available funds. In this study, we consider operating profit as a determinant of inefficiency. Tariffs and benefits are fundamental to the operation of public transport operators, because they are major sources of revenue for operators (Paulley et al. 2006). With operating profits, transport operators can improve the quality of services and indeed, improve efficiency. Operating profits are sources of internal financial investments in productive activity of the firm, consequently, operating profit can be considered as a determinant of inefficient transport operators.

Firm size plays an important role in most empirical research on strategic management (Wang et al. 2007). Size effects are so robust that researchers are working on a wide variety of research subjects (Macher, Boerner 2006). Lun and Quaddus (2011) study the effect of firm size on companies' efficiency and performance. They have shown that firm size has a relatively positive effect on efficiency and is a determinant of output growth. Halkos and Tzeremes (2007) argue that firm size has an indirect impact on firms' productivity because it determines the impact of internal productivity factors. They affirm that size can have a direct effect on productivity, and it is also a variable that improves firm efficiency. Consequently, we can consider firm size as one of the inefficiency determinants.

Consequently, the technical inefficiency model is defined by equation (6):

$$
\begin{aligned}
& \mu_{i t}=\delta_{0}+\delta_{1}(\text { invest })_{i t}+\delta_{2}(\text { Oper prof })_{i t}+ \\
& \delta_{3}(\text { Firm size })_{i t}+W_{i t},
\end{aligned}
$$

where: $\delta_{0}$ is a constant; (invest) $)_{i t}$ is the investment of operator $i$ in period $t$; (Oper prof $)_{i t}$ is the operating profit of operator $i$ in period $t$; (Firm size $)_{i t}$ is the firm size of operator $i$ in period $t ; W_{i t}$ is the error term. 


\section{Definitions of Inputs and Outputs}

Cullinane et al. (2004) provide a detailed discussion of the variables definition. This discussion has been summarised by Cullinane et al. (2006), affirming that the input and output variables should reflect the real objectives and the production process as precisely as possible. Public transport operator objectives are important determinants of the variables definition to measure efficiency. De Borger et al. (2002) and Jarboui et al. (2012) provide an overview of public transport efficiency studies and present the various inputs and outputs used in frontier studies.

The majority of the public transport efficiency studies use labour and capital as inputs. For example, Singh and Venkatesh (2003) use labour and the number of buses held as an appropriate measure of input. Other studies include energy to provide more detail on the inputs (Agrawal et al. 2006, 2009; Bishnoi, Sujata 2007; Nagadevara, Ramanayya 2008, 2010). Jarboui et al. (2012) show that financial variables are more robust, since they reduce the problems reflected by the use of demand or supply-oriented variables. They are relatively related and explanatory of the variables used initially. We find that most variables used to measure the inputs of a company are related to operating expenses. However, the use of traditional inputs such as labour, energy and vehicles, poses a problem of substitution between inputs. For transportation, this means that to produce an output level, bus or transport adopted operation could substitute labour for the vehicles, or vehicles substitute for energy. The usual remoteness of non-substitutable inputs leads to inefficient units reported as efficient. Since the increasing number of inputs and outputs gives high efficiency scores, therefore, due to the random error component in all variables, the more numerous inputs and outputs are the higher efficiency scores will be.

Consequently, we propose a single variable as a measure of output and two variables as inputs. We use the total operating expenses, which represent the sum of expenses related to the operation as an appropriate measure of inputs, and a proxy for physical inputs. Since we use Thomson Financial Database (Thomson One Banker 2012), the operating expenses of each company includes vehicle maintenance and operation, general maintenance, administration, total fees of the company committed to the subunit, or amortization (Thomson Reuters Financial 2012). In addition, Barnum and Gleason (2007) use the daily average of operating expenses as a measure of input. In the Italian context, Margari et al. (2007) use total operating expenses as one of the measures of inputs of 42 transportation companies. Barnum et al. (2011) adopt the total operating expenses as the only measure of inputs to measure the efficiency of 52 US transportation companies. They affirm that the total operating expenses represent the operations expense and maintenance of buses, maintenance not related to bus, and administration. In the public transport efficiency studies, it is conventional to use physical input, usually labour, energy and vehicles (De Borger et al. 2002).
However, a problem of substitutability between inputs arises (Barnum et al. 2011). Consequently, we use operating expenses as the main input. To properly present the inputs, we adopt the number of employees as a second input.

Most public transport efficiency studies use number of employees as an appropriate measure of inputs. Thus, Singh (2000a, 2000b, 2000c, 2000d) and Jha and Singh (2000) use the number of employees as the only measure of input. In addition, Agarwal et al. (2010), Kumar (2011), Saxena P. and Saxena, R. R. (2010), and Barros and Peypoch (2010) adopt the number of employees as one of the inputs measures. Consequently, the number of employees is the most used variable for inputs measuring in the public road transport efficiency studies. In view of this literature, we consider the total operating expenses and the number of employees as two reliable input measures of a public road transport operator, and which can be used in efficiency studies.

Indeed, the output definition poses important problem. To measure the output, efficiency studies focus on two indicator types, pure supply indicators (for example, vehicle-kilometres or square-kilometre) and demand indicators (for example, passenger-kilometres and number of passengers). Many studies affirm that outputs related to demand are very relevant to assessing firm efficiency (Chu et al. 1992; Costa 1998). Sheth et al. (2007), Sampaio et al. (2008), Yu and Fan (2009), Agarwal et al. (2010) and Saxena P. and Saxena, R. R. (2010) use the number of passenger-km as an output measure to evaluate the transport operators' efficiency. In addition, many studies use other indicators related to demand (i.e. the revenue or sales of the firm), as an appropriate output measure (Chang, Kao 1992; Chu et al. 1992; Cowie, Asenova 1999; Nolan et al. 2001; Boame 2004; Barros, Peypoch 2010; Kumar 2011; Jarboui et al. 2012). Consequently, in this study, we use the revenue to measure the output of public road transport operators. Since we use Thomson Financial Database, revenue is equal to sales, which is directly related to operating activities. This variable is an accurate measure of transported passengers.

\section{Data}

Econometric estimation models of frontier efficiency designed for cross-sectional data have many gaps in the estimation of technical efficiency (Schmidt, Sickles 1984). Model estimation and the separation of the two errors term components necessitate specific assumptions on the technical efficiency distribution and statistical random noise. In addition, error terms estimates for a particular observation contain both the conventional random error and technical inefficiency (Jondrow et al. 1982). Therefore, to get consistent estimators, it is necessary to impose the condition that the inefficiency term is independent of inputs.

Using panel data offers a better alternative for frontiers estimation than the use of the cross-sectional data. Panel data have two important advantages in the estima- 
tion of efficiency frontiers. First, the technical efficiency estimation of a specific firm can be achieved without resorting to errors distribution assumption. Second, it is not necessary to assume that technical efficiency is independent of inputs, but can be tested by avoiding the drawbacks of fixed effects (Schmidt, Sickles 1984; Hallam, Machado 1996). The existence of several observations over time for the same firm offers more reliable information about their efficiency. With panel data, the technical efficiency of transport operators can be estimated in a consistent way since the number of period $T$ tends to infinity.

In this study, the data consist of 648 annual observations. We use unbalanced panel data of 54 public road transport companies in different countries, publicly traded, during 2000-2011. We use Thomson Reuters Financial (2012) database to calculate the inputs, outputs and inefficiency explanatory variables. Thomson One Banker (2012) provides financial information companies of different countries from different databases (for example, the Worldscope Database and Datastream). Other data are directly available in the Worldscope Database (for example, total operating expenses, revenue, operating profit and investment). The number of employees is calculated from this data base by dividing the annual sales by the sales per employee. To measure firm size, we calculate the log of total assets of each company.

\section{Results}

The estimated parameters of production function frontier and inefficiency determinants are presented in Table 1. The coefficients and the efficiency scores of each transport operator are estimated using the program Frontier 4.1 (Battese, Coelli 1995). This program provides the parameter estimates of equations (5) and (6), and measures the efficiency scores of each transport operator.

\subsection{Descriptive Statistics}

The descriptive statistics of the variables used in this study are reported in Table 1. 'Panel A' represents the variables of the production function frontier. So, the average revenue of 54 firms between 2000 and 2011 is 18.654 million USD with a standard deviation 1.914 million USD. The average operating expenses and number of employees is respectively 18.641 million USD and 7.871 employees and a standard deviation of 1.907 million USD and 1.502 employees. 'Panel B' present the inefficiency determinants used in this study. We find that investment value varies between zero (the company has not invested) and 20.515 million USD (investment value in period T). About operating profit, we observe the existence of companies that have suffered losses. Based to our databases, specially the data of operating profit, BGS Germany has not made any gains during the twelveyear period, while other like CCOL Singapore has made gains. Indeed, the average firm size is 19.12 (log of total assets of company), and varies between 14.120 (e.g. DGIDPPSJSC Vietnam) and 22.986 (e.g. GOG United Kingdom).

Table 1 . Summary statistics of the variables

\begin{tabular}{lcccc}
\hline \multicolumn{1}{c}{ Variable } & Mean $\begin{array}{c}\text { Standard } \\
\text { deviation }\end{array}$ & Minimum & Maximum \\
\hline \multicolumn{4}{c}{ Panel A } \\
\hline $\begin{array}{l}\text { Revenue } \\
\text { [in million USD] }\end{array}$ & 18.654 & 1.914 & 13.632 & 23.056 \\
\hline $\begin{array}{l}\text { Total operating } \\
\text { expenses } \\
\text { [in million USD] }\end{array}$ & 18.641 & 1.907 & 13.062 & 22.989 \\
\hline $\begin{array}{l}\text { Number of } \\
\text { employee }\end{array}$ & 7.871 & 1.502 & 3.807 & 11.819 \\
\hline $\begin{array}{l}\text { Panel B } \\
\text { Investment } \\
\text { [in million USD] }\end{array}$ & 16.212 & 2.593 & 0 & 20.515 \\
\hline $\begin{array}{l}\text { Operating profit } \\
\text { [in million USD] }\end{array}$ & 9.276 & 13.27 & -19.320 & 20.332 \\
\hline $\begin{array}{l}\text { Size firm (log of } \\
\text { total assets) }\end{array}$ & 19.12 & 1.64 & 14.120 & 22.986 \\
\hline
\end{tabular}

\subsection{Technical Inefficiency Effects, Model Estimation and Hypotheses Testing}

As a common practice in the SFA model, a number of hypotheses were investigated in order to assess the relative influence of these explanatory factors and other random effects. The results of the null hypothesis tests associated with technical inefficiency effects are reported in Table 2. In order to select the best specification for the production function (Cobb-Douglas or translog) for the given data set, we conducted hypothesis tests for the parameters of the stochastic production frontier model using the generalized Likelihood-Ratio (LR) statistic. The hypothesis test results confirm that the translog production model is more appropriate for these data in comparison to the Cobb-Douglas production model. They also indicate that technical inefficiency effects are stochastic and are associated with the explanatory variables, namely investment, operating profit, and firm size. The result indicates that the technical inefficiency effects follow a generalised truncated normal distribution. That

Table 2. Results of hypotheses testing

\begin{tabular}{lcccc}
\hline \multicolumn{1}{c}{ Test } & Null hypothesis $\left(H_{0}\right)$ & Test statistic $($ LR test) & Critical value $\left(\chi_{\alpha}^{2}=0.05\right)$ & Decision \\
\hline Cobb-Douglas & $H_{0}: \beta_{3-5}=0$ & $392.85^{*}$ & 07.81 & Reject $H_{0}$ \\
\hline Stochastic effect & $H_{0}: \gamma=0$ & $139.14^{*}$ & 11.07 & Reject $H_{0}$ \\
\hline Inefficiency effects & $H_{0}: \gamma=\delta_{0-3}=0$ & $168.41^{*}$ & 07.81 & Reject $H_{0}$ \\
\hline
\end{tabular}

Note: ${ }^{*}$ Significant at five level. 
is, the procedure of Battese and Coelli (1995) does appear to be a significant improvement over the standard stochastic frontier model (which does not account for explanatory variables in the technical inefficiency effects). Therefore, the specified translog SFA production frontier is used in our next discussion.

\subsection{Stochastic Frontier Analysis Results}

This study specifies seven translog stochastic frontier production models' for the public road transport operators (Table 3). The computer program Frontier 4.1 (Coelli 1996) was used to estimate the parameters involved in the frontier model (Coelli, Battese 1996). The results of the Maximum-Likelihood (MLE) estimates for the parameters in the study are reported in Table 3 . The signs of the coefficients of the SFA models are consistent with expectations: the coefficients of the generation inputs are estimated to be positive. The result implies that there is a positive relationship between the inputs used and pub- lic transport operators' production. From the estimated coefficients of the total operating expenses and number of employee variables in the seventh model (which integrate all the variables, 0.763 and 0.035 , respectively), only the total operating expenses is significant at the $1 \%$ level.

On the other hand, the estimated coefficients of number of employees are relatively small and insignificant at the 5\% level. This result indicates that total operating expenses is a key factor of public transport production and therefore, any increase in these inputs will yield positive returns. The estimated coefficients of total operating expenses are significant at the $1 \%$ level in the seven models. This result confirms the assumptions of Barnum et al. (2011), who adopt the total operating expenses as the only inputs measurement to measure the efficiency of 52 US transportation companies.

The signs of the inefficiency determinants estimated coefficients $\left(\delta_{1}, \delta_{2}\right.$, and $\left.\delta_{3}\right)$ are negative and signifi-

Table 3. Estimated parameters of the translog SFA production function

\begin{tabular}{|c|c|c|c|c|c|c|c|c|}
\hline \multirow{2}{*}{ Variables } & \multirow{2}{*}{ Parameters } & \multicolumn{7}{|c|}{ Estimated MLE coefficients } \\
\hline & & Model 1 & Model 2 & Model 3 & Model 4 & Model 5 & Model 6 & Model 7 \\
\hline \multirow{2}{*}{ Constant } & \multirow{2}{*}{$\beta_{0}$} & 3.442 & 1.955 & 4.817 & 2.445 & 4.447 & 2.538 & 2.484 \\
\hline & & $(5.536)^{\star \star}$ & $(3.535)^{\star * *}$ & $(6.131)^{\star * *}$ & $(4.099)^{\star * \star}$ & $(6.127)^{* * *}$ & $(4.671)^{\star \star \star}$ & $(5.018)^{\star * *}$ \\
\hline \multirow{2}{*}{$\begin{array}{l}\text { Ln Total } \\
\text { operating } \\
\text { expenses }\end{array}$} & \multirow[b]{2}{*}{$\beta_{1}$} & 0.639 & 0.816 & 0.497 & 0.765 & 0.539 & 0.757 & 0.763 \\
\hline & & $(7.438)^{\star * \star}$ & $(9.635)^{* * *}$ & $(4.619)^{\star \star \star}$ & $(8.598)^{\star * *}$ & $(5.142)^{* * *}$ & $(9.087)^{\star * *}$ & $(9.997)^{\star * *}$ \\
\hline \multirow{2}{*}{$\begin{array}{l}\text { Ln Number } \\
\text { of employee }\end{array}$} & \multirow{2}{*}{$\beta_{2}$} & 0.103 & 0.034 & 0.129 & 0.036 & 0.112 & 0.039 & 0.035 \\
\hline & & $(1.27)$ & $(0.418)$ & $(1.371)$ & $(0.439)$ & $(1.138)$ & $(0.477)$ & $(0.443)$ \\
\hline \multirow{2}{*}{$\begin{array}{l}\text { (Ln Total } \\
\text { operating } \\
\text { expenses) }\end{array}$} & \multirow{2}{*}{$\beta_{3}$} & 0.014 & 0.0049 & 0.021 & 0.0074 & 0.019 & 0.0079 & 0.0075 \\
\hline & & $(2.528)^{* * *}$ & $(0.748)$ & $(2.856)^{\star \star \star \star}$ & (1.109) & $(2.457)^{\star * *}$ & $(1.219)$ & $(1.277)$ \\
\hline \multirow{2}{*}{$\begin{array}{l}\text { (Ln Number } \\
\text { of employee) })^{2}\end{array}$} & \multirow{2}{*}{$\beta_{4}$} & -0.025 & -0.0197 & -0.024 & -0.020 & -0.023 & -0.019 & -0.019 \\
\hline & & $(2.063)^{\star *}$ & $(1.548)$ & $(1.76)^{\star}$ & $(1.624)$ & $(2.030)^{\star *}$ & $(1.586)$ & $(1.644)$ \\
\hline \multirow{2}{*}{$\begin{array}{l}\text { (Ln Total } \\
\text { operating } \\
\text { expenses)* } \\
\text { (Ln Number } \\
\text { of employee) }\end{array}$} & \multirow{2}{*}{$\beta_{5}$} & 0.007 & 0.0075 & 0.0053 & 0.0075 & 0.0055 & 0.0074 & 0.0074 \\
\hline & & $(1.130)$ & $(0.987)$ & $(0.654)$ & $(1.029)$ & $(0.748)$ & $(1.013)$ & $(1.085)$ \\
\hline \multirow{2}{*}{ Constant } & \multirow{2}{*}{$\delta_{0}$} & 0.494 & -1038 & 12.147 & 0.010 & 11.479 & 1.513 & 0.847 \\
\hline & & $(1.215)$ & $(4.463)^{\star \star \star *}$ & $(6.243)^{\star * *}$ & $(0.057)$ & $(6.440)^{\star \star \star}$ & $(3.416)^{\star \star *}$ & $(1.367)$ \\
\hline \multirow{2}{*}{ Investment } & \multirow{2}{*}{$\delta_{1}$} & -0.459 & & & -0.059 & -0.093 & & -0.037 \\
\hline & & $(4.593)^{\star \star \star}$ & & & $(5.564)^{\star * \star}$ & $(4.348)^{\star \star \star}$ & & $(2.403)^{\star *}$ \\
\hline \multirow{2}{*}{$\begin{array}{l}\text { Operating } \\
\text { profit }\end{array}$} & \multirow{2}{*}{$\delta_{2}$} & & -0.088 & & -0.079 & & -0.071 & -0.074 \\
\hline & & & $(6.854)^{\star * *}$ & & $(18.827)^{\star * *}$ & & $(1.640)$ & $(11.682)^{* * *}$ \\
\hline \multirow{2}{*}{ Size firm } & \multirow{2}{*}{$\delta_{3}$} & & & -0.789 & & -0.686 & -0.123 & -0.058 \\
\hline & & & & $(5.657)^{\star \star \star}$ & & $(5.841)^{\star * *}$ & $(5.610)^{\star \star *}$ & $(1.782)^{\star}$ \\
\hline \multirow{2}{*}{ Sigma-squared } & \multirow{2}{*}{$\sigma^{2}=\sigma_{V}^{2}+\sigma_{U}^{2}$} & 1.189 & 0.128 & 0.538 & 0.0124 & 0.573 & 0.121 & 0.121 \\
\hline & & $(3.739)^{\star \star *}$ & $(10.372)^{\star * *}$ & $(4.847)^{\star * *}$ & $(9.160)^{\star \star *}$ & $(6.124)^{\star * *}$ & $(10.052)^{\star * *}$ & $(8.115)^{\star * *}$ \\
\hline \multirow{2}{*}{ Gamma } & $\sigma_{U}^{2}$ & 0.992 & 0.928 & 0.984 & 0.928 & 0.985 & 0.928 & 0.928 \\
\hline & $\gamma=\overline{\sigma_{V}^{2}+\sigma_{U}^{2}}$ & $(414.667)^{\star * *}$ & $(90.622)^{* * *}$ & $(252.580)^{\star * *}$ & $(76.879)^{\star \star \star}$ & $(314.504)^{\star * *}$ & $(86.747)^{\star * *}$ & $(81.229)^{* * *}$ \\
\hline \multicolumn{2}{|c|}{ Log likelihood function } & 140.516 & 309.233 & 149.207 & 318.412 & 151.279 & 317.571 & 319.210 \\
\hline
\end{tabular}

Notes: ${ }^{*},{ }^{* *},{ }^{* *}$ significant at the $10 \%, 5 \%$ and $1 \%$ levels respectively. 
cant in seven models. This implies a positive relationship between these variables (investment, operating profit and firm size) and technical efficiency in seven models estimated. This means that these variables negatively affect the transport operators' technical inefficiency. These variables assist the transport operators to be more efficient.

Gamma $(\gamma)$ is the ratio of the variance parameters of the random errors and technical efficiency effects, $\sigma_{V}^{2}$ and $\sigma_{U}^{2}$, which ranges between 0 and $1-$ it is noteworthy that the gamma cannot be considered to be a proportion of the variance of the technical inefficiency effects in relation to the total of the variances of the technical inefficiency effects and the random variation (Coelli, Battese 1996). In this empirical study, the estimated value of gamma is greater than zero and statistically significant at the $1 \%$ level in all the models. The result implies the presence of random component of the technical inefficiency effects and provides a better estimation of the technical efficiency of public transport operators. Consequently, the technical inefficiency effects are relatively significant for the random error term. Based on Table 2, this result rejects the null hypothesis, which there is no inefficiency effect $\left(H_{0}: \gamma=0\right)$. Therefore, the term $\mu_{i t}$ cannot be excluded from the regression and parameter estimation by the method of least squares (OLS) is inappropriate. This result justifies the error term decomposition and the presence of random terms inefficiency.

In addition, inefficiency of the production function is calculated by the error term. Using the composed error terms of the stochastic frontier model, it is defined by $\gamma=\sigma_{U}^{2} / \sigma_{V}^{2}+\sigma_{U}^{2}$, which is a measure of level of the inefficiency in the variance parameter which ranges between 0 and 1. It is observed that the MLE estimate of $\gamma$ is 0.9 (between 0.928 and 0.992) in the seven models. The value of $\gamma$ is significantly different from one indicating that random shocks play a significant role in explaining the variation in public road transport operators' production, which is expected in public transport production where uncertainty is assumed to be the main source of variation. This implies that the stochastic production frontier is significantly different from the deterministic frontier, which does not include a random error. In the MLE estimation, is positive and significant at $1 \%$ level, implying that public transport industry specific technical efficiency is important in explaining the total variability of yield produced. However, it should be noted that $99 \%$ of the variation in production is due to technical inefficiency and only $1 \%$ is due to the stochastic random error.

\subsection{Technical Efficiency Analysis of Selected Public Transport Operators}

The results for the technical efficiencies of public road transport operators are constructed from the SFA model as discussed in the previous section. The descriptive statistics of technical efficiency scores of the companies studied are reported in Table 4. The average technical efficiency score of transport operators during the twelve- year period is 0.89 while the minimum and maximum technical efficiency scores are respectively 0.10 (SAFE Indonesia) and 0.98 (SYTPHCo. China). Based on these results, the standard deviation of efficiency scores is generally small, reflecting that the level of technical efficiency of transport operators is generally constant during twelve-year period. However, the technical efficiency score of some firms has experienced an increasing trend (Table 4), for example the ROL of the United Kingdom (from 0.62 to 0.95 ), or a decreasing trend, for example, ZBRA of Indonesia (from 0.85 to 0.54 ).

\subsection{Technical Inefficiency Effects Model}

One of the objectives of this study is to identify the determinants of the technical efficiency of public transport operators. Results for each explanatory variable of the technical inefficiency effects model are presented in Table 3. All the signs of the coefficients are negative and consistent with our expectations. Under the four estimated models presented in Table 3, investment significantly explains the technical inefficiency of public transport operators. The first null hypothesis was rejected at the $5 \%$ level of significance, implying that technical efficiency is related to the investment level. The negative estimate of the investment coefficient indicates that the technical inefficiency of transport operators is explained by the low investment levels. Consequently, investment in terms of new technologies and new materials affects the technical efficiency of transport operators. Therefore, the greater the capital invested in the operating cycle is, the more the company is technically efficient. The result seems to be consistent with other research. For example, Ahern and Anandarajah (2007) study the priority of investment in the transport sector. They show that investment is a necessity to improve quality, reliability and transportation system security and to increase passenger demand for public transport services.

The second null hypothesis considered in Table 3 specifies that technical efficiency is not related to operating profit. This null hypothesis was rejected at the $5 \%$ level of significance. This result consolidates the affirmation of Paulley et al. (2006), which showed that the benefits are fundamental to the public transport operators operation. Technical efficiency can be affected by the availability of financial resources. Once a company no longer has access to external financial resources, there is an interest in improving their technical efficiency over time in order to ensure positive profits and productivity gains (Sena 2006). Based on this variable, transport operators in our sample can be classified into three groups: positive profit, negative profit and positive/ negative profit.

First, the group which has positive operating profit in the entire study period is characterized by a high level of technical efficiency (for example, PTHL Hong Kong, GOG United Kingdom, JCCo. China and SIX2 from Germany). They have made an average efficiency score equal $0.955,0.960,0.966$, and 0.965 respectively (Table 4). The second group is constituted of firms that have negative operating profits, represents companies 
Table 4. Technical efficiency of public road transport by company

\begin{tabular}{|c|c|c|c|c|c|}
\hline Firm & Country & Mean & Standard deviation & Minimum & Maximum \\
\hline SYTPHCo. & China & 0.9836 & 0.0036 & 0.9770 & 0.9886 \\
\hline SFTGCo. & China & 0.9757 & 0.0008 & 0.9748 & 0.9763 \\
\hline CCOL & Singapore & 0.9682 & 0.0025 & 0.9643 & 0.9710 \\
\hline FGP & United Kingdom & 0.9666 & 0.0008 & 0.9653 & 0.9678 \\
\hline JCCo. & China & 0.9660 & 0.0036 & 0.9631 & 0.9748 \\
\hline JSL S.A. & Brazil & 0.9659 & 0.0023 & 0.9643 & 0.9686 \\
\hline SIX2 & Germany & 0.9654 & 0.0042 & 0.9598 & 0.9707 \\
\hline SQHCo. & China & 0.9650 & 0.0016 & 0.9619 & 0.9666 \\
\hline DGIDPPSJSC & Vietnam & 0.9641 & 0.0212 & 0.9402 & 0.9807 \\
\hline TIHL & Hong Kong & 0.9640 & 0.0229 & 0.8985 & 0.9833 \\
\hline SHCo. & China & 0.9636 & 0.0074 & 0.9450 & 0.9715 \\
\hline NANSOTrCo. & Japan & 0.9629 & 0.0014 & 0.9595 & 0.9645 \\
\hline GOG & United Kingdom & 0.9605 & 0.0020 & 0.9566 & 0.9634 \\
\hline DTGCo. & China & 0.9601 & 0.0050 & 0.9534 & 0.9692 \\
\hline DKSCo. & Japan & 0.9597 & 0.0019 & 0.9562 & 0.9626 \\
\hline NKCo. & Japan & 0.9585 & 0.0035 & 0.9526 & 0.9642 \\
\hline JETT & Jordan & 0.9581 & 0.0044 & 0.9532 & 0.9644 \\
\hline KCKCo. & Japan & 0.9581 & 0.0019 & 0.9546 & 0.9613 \\
\hline SPTCo. & Saudi Arabia & 0.9571 & 0.0061 & 0.9450 & 0.9663 \\
\hline SBCo. & Japan & 0.9552 & 0.0017 & 0.9526 & 0.9583 \\
\hline PTHL & Hong Kong & 0.9548 & 0.0039 & 0.9477 & 0.9587 \\
\hline UITCo & Saudi Arabia & 0.9534 & 0.0131 & 0.9279 & 0.9701 \\
\hline SLCo. & Japan & 0.9507 & 0.0020 & 0.9481 & 0.9539 \\
\hline VNS & Vietnam & 0.9488 & 0.0140 & 0.9340 & 0.9673 \\
\hline HCBCo. & Japan & 0.9487 & 0.0034 & 0.9414 & 0.9528 \\
\hline SBSTr & Singapore & 0.9475 & 0.0393 & 0.8230 & 0.9630 \\
\hline DEBCo. & Korea (South) & 0.9470 & 0.0180 & 0.9113 & 0.9608 \\
\hline STB & Canada & 0.9470 & 0.0112 & 0.9218 & 0.9558 \\
\hline RUMM & Jordan & 0.9396 & 0.0100 & 0.9311 & 0.9544 \\
\hline KCBHL & Hong Kong & 0.9369 & 0.0287 & 0.8479 & 0.9522 \\
\hline SMTCo. & Japan & 0.9328 & 0.0360 & 0.8509 & 0.9525 \\
\hline SJIIICo. & China & 0.9291 & 0.0861 & 0.6703 & 0.9623 \\
\hline WEHA & Indonesia & 0.9277 & 0.0108 & 0.9108 & 0.9399 \\
\hline SGC & United Kingdom & 0.9243 & 0.0506 & 0.8385 & 0.9689 \\
\hline NZCo. & China & 0.9128 & 0.0560 & 0.7952 & 0.9529 \\
\hline SBC & Vietnam & 0.9079 & 0.0245 & 0.8816 & 0.9373 \\
\hline NKA1R & Latvia & 0.9078 & 0.0430 & 0.8136 & 0.9372 \\
\hline TIDE & Norway & 0.9009 & 0.0574 & 0.7865 & 0.9595 \\
\hline KTB & Malaysia & 0.8920 & 0.0703 & 0.7937 & 0.9516 \\
\hline CHEX & Korea (South) & 0.8860 & 0.0656 & 0.7753 & 0.9421 \\
\hline KBES & Malaysia & 0.8619 & 0.1050 & 0.6928 & 0.9732 \\
\hline ROL & United Kingdom & 0.8606 & 0.1413 & 0.6198 & 0.9553 \\
\hline ZIP & United States & 0.8545 & 0.0475 & 0.7807 & 0.8976 \\
\hline PEK & Poland & 0.8539 & 0.0540 & 0.8012 & 0.9426 \\
\hline ALFA & Jordan & 0.8439 & 0.1226 & 0.6870 & 0.9537 \\
\hline TTCo. & Vietnam & 0.8225 & 0.1373 & 0.7163 & 0.9775 \\
\hline CMPP & Indonesia & 0.7865 & 0.1713 & 0.4920 & 0.9475 \\
\hline ZBRA & Indonesia & 0.7448 & 0.1801 & 0.5312 & 0.9462 \\
\hline UNIF & Jordan & 0.7256 & 0.1844 & 0.3948 & 0.9124 \\
\hline ABUS & Jordan & 0.7131 & 0.0656 & 0.6474 & 0.8123 \\
\hline SAFE & Indonesia & 0.6260 & 0.2953 & 0.1001 & 0.9538 \\
\hline HVB & Germany & 0.5813 & 0.1421 & 0.3504 & 0.7660 \\
\hline BGS & Germany & 0.5131 & 0.0332 & 0.4666 & 0.5833 \\
\hline BRS & Germany & 0.4371 & 0.0702 & 0.3249 & 0.5406 \\
\hline \multicolumn{2}{|l|}{ All the operators } & 0.8907 & 0.0462 & 0.1001 & 0.9886 \\
\hline
\end{tabular}


that have achieved losses during their operating cycle. Technical efficiency of this group is usually low. For example, BGS and BRS of Germany and UNIF Jordan have made technical efficiency scores of $0.513,0.437$, and 0.726 respectively. The third group, companies have both positive and negative operating profit, is characterized by a medium technical efficiency, which is less than the first group and higher than the second (for example ZBRA of Indonesia (0.745) and PEK of Poland $(0.854))$. Referring to Table 3, the negative coefficient estimation of operating profit indicates that technical inefficiency can be explained by the variation of this variable. Consequently, we can conclude that companies that achieve a positive operating profit are more efficient than those that have negative operating profit.

The third null hypothesis contends that technical efficiency does not vary with firm size. This hypothesis was not rejected at the $1 \%$ level of significance in the three models. The estimated coefficient of firm size is negative. This result indicates that larger public transport operators are more technically efficient than the smaller public transport operators and this result implies that large firms are able to invest more than small firms by integrating new technologies and assets increase. This finding agrees with those of other studies, like Lun and Quaddus (2011) who study the effect of firm size on company efficiency and performance. They show that firm size has a relatively positive effect on efficiency and is a determinant of output growth. In addition, Hawawini et al. (2003) found that firm size can be a source of competitive advantage and that large firms are assumed to be relatively more efficient than smaller ones.

In this study, we find that the technical inefficiency of transport operators can be explained by the investment level, operating profit, and firm size. These variables are indicators of managerial efficiency. Consequently, the technical efficiency of transport operators is directly related to managerial efficiency. On the other hand, managerial efficiency affects positively firms' technical efficiency. Public transport operators can improve technical efficiency by improving managerial efficiency. This finding agrees with those of other studies. Cowie (2002) found that technical and managerial efficiency follows a similar trend. Consequently, the discussion of technical and managerial efficiency may be a new area of research in the efficiency of transport operators.

\subsection{Public Transport Operators' Efficiency in Developed and Developing Countries}

According to the countries classification by World Bank (http://www.worldbank.org), we classify the studied countries in this research in two groups: Developed and developing countries. The average technical efficiency of the public transport sector in developed and developing countries is presented in Fig. The average technical efficiency curve of transport operators in developed countries is generally higher than developing countries' curve, except for the years 2003, 2004 and 2005. Referring to Fig., generally, public transport operators in

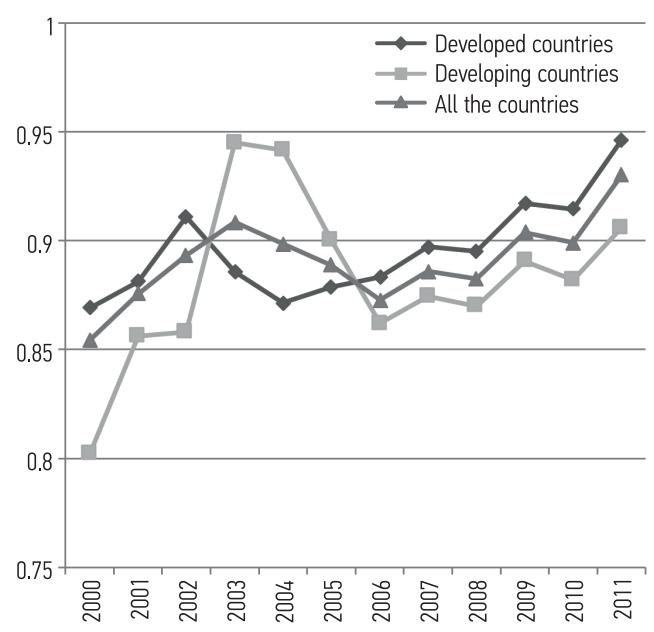

Fig. Average technical efficiency of developed and developing countries

developed countries have realized an average technical efficiency scores higher than transport operators of developing countries.

Referring to Table 5 and Fig., the average technical efficiency of public road transport operators of developed and developing countries tend to have an increasing trend during the study period. The average technical efficiency of operators in developed countries tends to follow an increasing trend in the first three years until 2002. However, the average efficiency dropped between 2002 and 2004, which could be explained by a decrease in investment in this sector coinciding with a reduction in yield of equipment used. Indeed, operating profits are reduced or become negative as presented in Section 6.5. After 2004, average efficiency increases gradually and achieved 0.95 in 2011 . The average efficiency of public transport operators in developing countries increased rapidly in the first four years from 0.80 in 2000 to 0.95 in 2003. In the next three years, the average efficiency dropped and achieved 0.85 , which could be relatively related to the technology level and capital invested by these operators (Table 3). After 2007, the average efficiency of developing countries had a low increasing trend of 0.05 . However, it should be noted that we can find a different efficiency levels of public transport between the different operators' within the same group of developed or developing countries (Table 5).

Generally, public transport operators in developed countries are more efficient than operators in developing countries (Table 5). In contrast to developed countries, developing countries face great challenges in their efforts towards economic development, such as socio-economic changes, education, health, and environment. And so, public transport has been largely ignored. As a result of population growth and increased motorisation, the pressure on public transport systems has increased and, public transport is ignored in favour of cars (personal transportation) (Banister 2006). In addition, wherever governments invest in the transportation sector, it is often aimed at automobile infrastructure (roads and parking spaces), which is less interesting to the major- 
Table 5. Technical efficiency of public road transport by country

\begin{tabular}{lcccc}
\hline Country & Mean & $\begin{array}{c}\text { Standard } \\
\text { deviation }\end{array}$ & Min & Max \\
\hline & Developed counties & & \\
\hline Hong Kong & 0.9504 & 0.0136 & 0.9122 & 0.9629 \\
\hline Canada & 0.9470 & 0.0112 & 0.9218 & 0.9558 \\
\hline Germany & 0.6242 & 0.0556 & 0.5349 & 0.6976 \\
\hline Japan & 0.9532 & 0.0042 & 0.9443 & 0.9567 \\
\hline Korea (South) & 0.9002 & 0.0595 & 0.7845 & 0.9485 \\
\hline Norway & 0.9009 & 0.0574 & 0.7865 & 0.9595 \\
\hline Singapore & 0.9572 & 0.0202 & 0.8936 & 0.9669 \\
\hline United States & 0.8545 & 0.0475 & 0.7807 & 0.8976 \\
\hline United Kingdom & 0.9401 & 0.0366 & 0.8534 & 0.9659 \\
\hline Brazil & Developing & countries & & \\
\hline China & 0.9659 & 0.0023 & 0.9643 & 0.9686 \\
\hline Indonesia & 0.9551 & 0.0136 & 0.9206 & 0.9655 \\
\hline Jordan & 0.7513 & 0.0879 & 0.6447 & 0.9031 \\
\hline Latvia & 0.8435 & 0.0681 & 0.7386 & 0.9351 \\
\hline Malaysia & 0.9078 & 0.0430 & 0.8136 & 0.9372 \\
\hline Poland & 0.8879 & 0.0746 & 0.7502 & 0.9732 \\
\hline Saudi Arabia & 0.8539 & 0.0540 & 0.8012 & 0.9426 \\
\hline Vietnam & 0.9212 & 0.0347 & 0.8821 & 0.9791 \\
\hline All the countries & 0.8928 & 0.0265 & 0.5349 & 0.9791 \\
\hline
\end{tabular}

ity of the population (Saxena, P., Saxena, R. R. 2010). Generally, the low investment level is the first factor explaining the low efficiency level of public transport in developing countries.

Generally, investment financing in public transport cannot be fully covered by transport operators' revenues. Outside financial support is often necessary to bridge the gap between tariffs profit and investment costs (Sheth et al. 2007).

\section{Conclusions}

1. Efficiency evaluation is a well-known issue in economic literature. Generally, most efficiency studies are aimed at measuring the efficiency and development of methods to assess transport operators' efficiency. However, inefficiency determinants research has been ignored or explained by only exogenous factors. Thus, the determinants of transport operators' inefficiency remain obscure. Efficiency improvement and progress assessment towards achieving the goals are important tools in the implementation of an effective business strategy, service delivery, and service quality.

2. In this paper, the aim was to contribute to the efficiency analysis of public transport operators. We use a data set of the World-scope and Thomson database composed of 54 public transport operators in differ- ent countries over a twelve-year period (2000-2011) for two purposes: to measure the efficiency of public transport operators and, to study the determinants of the inefficiency of transport operators. Using the Stochastic Frontier Analysis (SFA) method, efficiency is estimated under the specification of a translog production frontier.

3. The major contribution in this paper is to identify the inefficiency determinants. As opposed to other studies on the public transport operators' efficiency, this study attempts to explain inefficiency by variables under operators' control. This study highlights the key role of investment, operating profit and firm size. Moreover, investment in terms of new technologies, new materials and the necessary formation in new materials technology has an influence on the technical efficiency of transport operators. This finding is in agreement with the study of Ahern and Anandarajah (2007), who study the priority of investment in the transport sector. They show that investment is necessary to improve the quality, reliability, and transportation system security and to increase passenger demand for public transport services.

4. Total operating expenses are fundamental factors in public transport operators' production performance. Therefore, any variation of this variable will affect the operators' performance. The average technical efficiency level of public transport operators studied equals 0.89 . The most efficient operators can be considered as operators of best practices to be followed by less efficient operators to improve their efficiency levels within the group. Generally, the efficiency scores of transport operators has progressively increased over the past twelve years. In this study, the transport operators' efficiency level of developed countries is higher than the developing countries operators. Developing countries are confronted with major challenges in their efforts towards economic development, such as social-economic changes, education, health, and environment. However, in many cases, public transport remains largely neglected.

5. Operating profit is strategic to public transport operators operation, because it is a major source of revenue for operators. Technical efficiency can be affected by the availability of financial resources; once companies can no longer access external financial resources; then it becomes interested in improving their technical efficiency over time by ensuring operating profit.

6. Large-size public transport operators are technically more efficient than smaller-size operators. This result implies that large-size firms have an opportunity to invest more than small-size firms by integrating new technologies and increasing assets, and thus, the firm size increases, which affects their technical efficiency. Therefore, firm size has a relatively positive effect on efficiency, and it is a determinant of output growth. Since, firm size can be a source of competitive advantage; large-size firms are relatively more efficient than smaller ones. 
7. This study has certain limits that should be surmounted in future research in this area. The major drawback concerns the geographical characteristic of the region in which the public transport operators work. This information would probably help to explain the differences in efficiency between operators examined. Expand the data set of input variables to take account environmental or instrumental variables (contextual), such as geographic proximity to mainline operations. Use the efficiency of operators' estimates, in parallel with other variables, to explain the choice of operators' in a modelling methodology of discrete choice. The aim is to explain and predict the operators' competitiveness and market share. Government subsidy is a source of revenue for some public transport operators'. However, in this study, government subsidy is not considered as part of operator's revenue.

8. Despite these limitations, the results of this study are interesting for policy-makers and transport company managers. They can allow better understanding inefficiencies and giving more consideration to efficiency determinants.

\section{References}

Agarwal, S.; Yadav, S. P.; Singh, S. P. 2010. DEA based estimation of the technical efficiency of state transport undertakings in India, Opsearch 47(3): 216-230.

http://dx.doi.org/10.1007/s12597-011-0035-4

Agarwal, S. Yadav, S. P.; Singh, S. P. 2009. Total factor productivity growth in the state road transport undertakings of India: an assessment through MPI approach, Indian Economic Review 44(2): 203-223.

Agrawal, S.; Yadav, S. P.; Singh, S. P. 2006. A data envelopment based efficiency assessment of public transit sector of Uttar Pradesh State in India, Indian Journal of Transport Management 30(1): 5-30.

Ahern, A.; Anandarajah, G. 2007. Railway projects prioritisation for investment: application of goal programming, Transport Policy 14(1): 70-80. http://dx.doi.org/10.1016/j.tranpol.2006.10.003

Aigner, D. J.; Chu, S. F. 1968. On estimating the industry production function, American Economic Review 58(4): 826-839.

Aigner, D.; Lovell, C. A. K.; Schmidt, P. 1977. Formulation and estimation of stochastic frontier production function models, Journal of Econometrics 6(1): 21-37. http://dx.doi.org/10.1016/0304-4076(77)90052-5

Banister, D. 2006. Cities, urban form and sprawl: a European perspective, in Report of the One Hundred and Thirty Seventh Round Table on Transport Economics: Transport, Urban Form and Economic Growth, 113-142.

Barnum, D. T.; Gleason, J. M. 2007. Technical efficiency bias in data envelopment analysis caused by intra-output aggregation, Applied Economics Letters 14(9): 623-626. http://dx.doi.org/10.1080/13504850500461647

Barnum, D. T.; Karlaftis, M. G.; Tandon, S. 2011. Improving the efficiency of metropolitan area transit by joint analysis of its multiple providers, Transportation Research Part E: Logistics and Transportation Review 47: 1160-1176. http://dx.doi.org/10.1016/j.tre.2011.04.006

Barros, C. P.; Peypoch, N. 2010. Productivity changes in Portuguese bus companies, Transport Policy 17(5): 295-302. http://dx.doi.org/10.1016/j.tranpol.2010.02.003
Baten, M. A.; Kamil, A. A.; Haque, M. A. 2009. Modeling technical inefficiencies effects in a stochastic frontier production function for panel data, African Journal of Agricultural Research 4(12): 1374-1382.

Battese, G. E.; Coelli, T. J. 1993. A stochastic frontier production function incorporating a model for technical inefficiency effects, Working Papers in Econometrics and Applied Statistics 69: 1-27.

Battese, G. E.; Coelli, T. J. 1995. A model for technical inefficiency effects in a stochastic frontier production function for panel data, Empirical Economics 20(2): 325-332. http://dx.doi.org/10.1007/BF01205442

Bishnoi, N. K.; Sujata, U. 2007. Efficiency assessment of Haryana State Roadways: a data envelopment analysis, Indian Journal of Transport Management 32(1): 9-23.

Bjurek, H.; Hjalmarsson, L.; Forsund, F. R. 1990. Deterministic parametric and nonparametric estimation of efficiency in service production: a comparison, Journal of Econometrics 46(1-2): 213-227. http://dx.doi.org/10.1016/0304-4076(90)90056-Y

Boame, A. K. 2004. The technical efficiency of Canadian urban transit systems, Transportation Research Part E: Logistics and Transportation Review 40(5): 401-416. http://dx.doi.org/10.1016/j.tre.2003.09.002

Chang, K.-P.; Kao, P.-H. 1992. The relative efficiency of public versus private municipal bus firms: an application of data envelopment analysis, Journal of Productivity Analysis 3(12): 67-84. http://dx.doi.org/10.1007/BF00158769

Charnes, A.; Cooper, W. W.; Rhodes, E. 1978. Measuring the efficiency of decision making units, European Journal of Operational Research 2(6): 429-444. http://dx.doi.org/10.1016/0377-2217(78)90138-8

Christensen, L. R.; Jorgenson, D. W.; Lau, L. J. 1973. Transcendental logarithmic production frontiers, The Review of Economics and Statistics 55(1): 28-45. http://dx.doi.org/10.2307/1927992

Chu, X.; Fielding, G. J.; Lamar, B. W. 1992. Measuring transit performance using data envelopment analysis, Transportation Research Part A: Policy and Practice 26(3): 223-230. http://dx.doi.org/10.1016/0965-8564(92)90033-4

Cobb, C. W.; Douglas, P. H. 1928. A theory of production, The American Economic Review 18(1): 139-165.

Coelli, T. J. 1996. A Guide to Frontier Version 4.1: A Computer Program. University of New England, Armidale, Australia.

Coelli, T. J.; Battese, G. E. 1996. Identification of factors which influence the technical inefficiency of Indian farmers, Australian Journal of Agricultural and Resource Economics 40(2): 103-128. http://dx.doi.org/10.1111/j.1467-8489.1996.tb00558.x

Costa, A. 1998. Public transport efficiency and effectiveness: metro de Madrid, in K. Button, P. Nijkamp, H. Priemus (Eds.). Transport Networks in Europe: Concepts, Analysis and Policies, 248-264.

Cowie, J. 2002. Acquisition, efficiency and scale economies: an analysis of the British bus industry, Transport Reviews 22(2): 147-157. http://dx.doi.org/10.1080/014416400110076267

Cowie, J.; Asenova, D. 1999. Organisation form, scale effects and efficiency in the British bus industry, Transportation 26(3): 231-248. http://dx.doi.org/10.1023/A:1005121506841

Cullinane, K.; Song, D.-W.; Ji, P.; Wang, T.-F. 2004. An application of DEA windows analysis to container port production efficiency, Review of Network Economic 3(2): 184-206. http://dx.doi.org/10.2202/1446-9022.1050 
Cullinane, K.; Wang, T.-F.; Song, D.-W.; Ji, P. 2006. The technical efficiency of container ports: comparing data envelopment analysis and stochastic frontier analysis, Transportation Research Part A: Policy and Practice 40(4): 354-374. http://dx.doi.org/10.1016/j.tra.2005.07.003

De Borger, B.; Kerstens, K.; Costa, Á. 2002. Public transit performance: What does one learn from frontier studies?, Transport Reviews 22(1): 1-38. http://dx.doi.org/10.1080/01441640010020313

Färe, R.; Grosskopf, S.; Lovell, C. A. K. 1985. The Measurements of Efficiency of Production. Springer. $216 \mathrm{p}$.

Farrell, M. J. 1957. The measurement of productive efficiency, Journal of the Royal Statistical Society. Series A (General) 120(3): 253-290. http://dx.doi.org/10.2307/2343100

Ferrier, G. D.; Lovell, C. A. K. 1990. Measuring cost efficiency in banking: econometric and linear programming evidence, Journal of Econometrics 46(1-2): 229-245. http://dx.doi.org/10.1016/0304-4076(90)90057-Z

García Sánchez, I. M. 2009. Technical and scale efficiency in spanish urban transport: estimating with data envelopment analysis, Advances in Operations Research 2009: 1-15. http://dx.doi.org/10.1155/2009/721279

Halkos, G. E.; Tzeremes, N. G. 2007. Productivity efficiency and firm size: an empirical analysis of foreign owned companies, International Business Review 16(6): 713-731. http://dx.doi.org/10.1016/j.ibusrev.2007.06.002

Hallam, D.; Machado, F. 1996. Efficiency analysis with panel data: a study of Portuguese dairy farms, European Review of Agricultural Economics 23(1): 79-93. http://dx.doi.org/10.1093/erae/23.1.79

Hawawini, G.; Subramanian, V.; Verdin, P. 2003. Is performance driven by industry-or firm-specific factors? A new look at the evidence, Strategic Management Journal 24(1): 1-16. http://dx.doi.org/10.1002/smj.278

Jarboui, S.; Forget, P.; Boujelbene, Y. 2012. Public road transport efficiency: a literature review via the classification scheme, Public Transport 4(2): 101-128. http://dx.doi.org/10.1007/s12469-012-0055-3

Jha, R.; Singh, S. K. 2000. Small is efficient: a frontier approach to cost inefficiencies in Indian state road transport undertakings, International Journal of Transport Economics 28(1): 95-114. http://dx.doi.org/10.2139/ssrn.228829

Jondrow, J.; Lovell, C. A. K.; Materov, I. S.; Schmidt, P. 1982. On the estimation of technical inefficiency in the stochastic frontier production function model, Journal of Econometrics $19(2-3)$ : 233-238. http://dx.doi.org/10.1016/0304-4076(82)90004-5

Karlaftis, M. G. 2010. Ownership and competition in European transit: assessing efficiency, Transportmetrica 6(2): 143-160. http://dx.doi.org/10.1080/18128600903034342

Karlaftis, M.; McCarthy, P. 1999. The effect of privatization on public transit costs, Journal of Regulatory Economics 16(1): 27-44. http://dx.doi.org/10.1023/A:1008179629733

Karlaftis, M. G.; McCarthy, P. 2002. Cost structures of public transit systems: a panel data analysis, Transportation Research Part E: Logistics and Transportation Review 38(1): 1-18. http://dx.doi.org/10.1016/S1366-5545(01)00006-0

Karlaftis, M. G.; Tsamboulas, D. 2012. Efficiency measurement in public transport: Are findings specification sensitive?, Transportation Research Part A: Policy and Practice 46(2): 392-402. http://dx.doi.org/10.1016/j.tra.2011.10.005

Kumar, S. 2011. State road transport undertakings in India: technical efficiency and its determinants, Benchmarking:
An International Journal 18(5): 616-643.

http://dx.doi.org/10.1108/14635771111166794

Lovell, C. A. K. 1993. Production frontier and productive efficiency, in H. O. Fried, C. A. K. Lovell, S. S. Schmidt (Eds.) The Measurement of Productive Efficiency: Techniques and Applications, Oxford University Press, 3-67.

Lun, Y. H. V.; Quaddus, M. A. 2011. Firm size and performance: a study on the use of electronic commerce by container transport operators in Hong Kong, Expert Systems with Applications 38(6): 7227-7234.

http://dx.doi.org/10.1016/j.eswa.2010.12.029

Macher, J. T.; Boerner, C. S. 2006. Experience and scale and scope economies: trade-offs and performance in development, Strategic Management Journal 27(9): 845-865. http://dx.doi.org/10.1002/smj.540

Margari, B. B.; Erbetta, F.; Petraglia, C.; Piacenza, M. 2007. Regulatory and environmental effects on public transit efficiency: a mixed DEA-SFA approach, Journal of Regulatory Economics 32(2): 131-151. http://dx.doi.org/10.1007/s11149-007-9025-0

Meeusen, W.; Van den Broeck, J. 1977. Efficiency estimation from Cobb-Douglas production function with composed error, International Economic Review 18(2): 435-444. http://dx.doi.org/10.2307/2525757

Mohapatra, P. K. J.; Dutta, R. K. 1990. An intermodal investment decision model in the transport sector, Omega 18(2): 203-212. http://dx.doi.org/10.1016/0305-0483(90)90067-J

Nagadevara, V.; Ramanayya, T. V. 2010. Inter-temporal shifts in efficiency in a road transport organization, Journal of the Academy of Business and Economics 10(1): 139-144.

Nagadevara, V.; Ramanayya, T. V. 2008. Evaluating efficiency of subunits of state owned transport undertakings using data envelopment analysis, International Journal of Business Strategy 8(1): 103-109.

Nolan, J. F.; Ritchie, P. C.; Rowcroft, J. R. 2001. Measuring efficiency in the public sector using nonparametric frontier estimators: a study of transit agencies in the USA, Applied Economics 33(7): 913-922. http://dx.doi.org/10.1080/00036840122663

Paulley, N.; Balcombe, R.; Mackett, R.; Titheridge, H.; Preston J.; Wardman, M.; Shires, J.; White, P. 2006. The demand for public transport: the effects of fares, quality of service, income and car ownership, Transport Policy 13(4): 295306. http://dx.doi.org/10.1016/j.tranpol.2005.12.004

Reifschneider, D.; Stevenson, R. 1991. Systematic departures from the frontier: a framework for the analysis of firm inefficiency, International Economic Review 32(3): 715-723. http://dx.doi.org/10.2307/2527115

Sampaio, B. R.; Neto, O. L.; Sampaio, Y. 2008. Efficiency analysis of public transport systems: lessons for institutional planning, Transportation Research Part A: Policy and Practice 42(3): 445-454. http://dx.doi.org/10.1016/j.tra.2008.01.006

Saxena, P.; Saxena, R. R. 2010. Measuring efficiencies in Indian public road transit: a data envelopment analysis approach, Opsearch 47(3): 195-204. http://dx.doi.org/10.1007/s12597-011-0034-5

Schmidt, P.; Sickles, R. C. 1984. Production frontiers and panel data, Journal of Business and Economic Statistics 2(4):367-374.

Sena, V. 2006. The determinants of firms' performance: can finance constraints improve technical efficiency?, European Journal of Operational Research 172(1): 311-325. http://dx.doi.org/10.1016/j.ejor.2004.07.071

Sheth, C.; Triantis, K.; Teodorović, D. 2007. Performance evaluation of bus routes: a provider and passenger perspective, 
Transportation Research Part E: Logistics and Transportation Review 43(4): 453-478.

http://dx.doi.org/10.1016/j.tre.2005.09.010

Singh, S. K. 2000a. Productive efficiency across firms: state road transport undertakings, Economic and Political Weekly 35(48): 4269-4275.

Singh, S. K. 2000b. Productive efficiency and its convergence across firms: the case of state road transport undertakings in India, in Proceedings of the Conference on Industrialization in a Reforming Economy: a Quantitative Assessment to honour Prof. K. L. Krishna, 20-22 December 2000, Delhi School of Economics, Delhi.

http://dx.doi.org/10.2139/ssrn.234865

Singh, S. K. 2000c. State road transport undertakings, 1983-84 to 1996-97: a multilateral comparison of total factor productivity, Indian Journal of Transport Management 24(5): 363-388.

Singh, S. K. 2000d. Technical characteristics and efficiency of the Indian state road transport undertakings, Indian Journal of Transport Management 24(8): 533-543.

Singh, S. K.; Venkatesh, A. 2003. Comparing efficiency across state transport undertakings: a production frontier approach, Indian Journal of Transport Management 27(3): 374-391.

Thomson One Banker. 2012. Thomson Reuters. Available from Internet: http://banker.thomsonib.com

Thomson Reuters Financial. 2012. Thomson Reuters. Available from Internet: http://thomsonreuters.com/products_services/financial

Von Hirschhausen, C.; Cullmann, A. 2010. A nonparametric efficiency analysis of German public transport companies, Transportation Research Part E: Logistics and Transportation Review 46(3): 436-445. http://dx.doi.org/10.1016/j.tre.2009.11.005

Wang, L. M.; Liu, L. W.; Wang, Y. J. 2007. Capacity decisions and supply price games under flexibility of backward integration, International Journal of Production Economics 110(1-2): 85-96.

http://dx.doi.org/10.1016/j.ijpe.2007.02.011

Yu, M.-M.; Fan, C.-K. 2009. Measuring the performance of multimode bus transit: a mixed structure network DEA model, Transportation Research Part E: Logistics and Transportation Review 45(3): 501-515.

http://dx.doi.org/10.1016/j.tre.2008.10.001 